\title{
FAILURE: A CONCEPTUAL PROPOSAL TO RETHINK THE CARIBBEAN
}

\section{Fracaso: una propuesta conceptual para repensar lo caribeño}

\author{
MAgdaLENA LóPEZ \\ Centro de Estudios Compartistas, Universidad de LISBOA \\ magdalenalopez626@hotmail.com
}

\begin{abstract}
I offer a conceptualization of failure as a constitutive experience of Caribbeanness. Failure produces the need to reformulate a history that turned out differently from that initially intended, encouraging the uprooting of interpretative assumptions. Rootlessness, therefore, refers not only national or geographic displacement, but also to the loss of certainties upon which our vision of the world is based. This rootlessness impels us to drift away from the epic assumptions on which social, political or national identities have been established to seek more inclusive forms of community. I show both the potential of failure and the dangers of denying it through the study of ten Hispanic Caribbean narratives written in the 21th Century.

Keywords: Failure, Rootlessness, Epic, Caribbean Literature
\end{abstract}

Resumen: propongo una conceptualización del fracaso como experiencia constitutiva de lo caribeño. El fracaso conlleva a la necesidad de reformular una historia distinta a la que inicialmente se creía, incitando un desenraizamiento constante de las premisas interpretativas. Entiendo, así, el desarraigo ya no simplemente como una dislocación geográfica o nacional, sino como la pérdida de las certidumbres sobre las que se fundamenta nuestra visión del mundo. El desarraigo obligaría a abandonar las premisas épicas sobre las que se han asentado las identidades sociales, políticas o nacionales para apuntar a formas más inclusivas de comunidad. A través del estudio de diez narrativas del Caribe insular hispano del siglo XXI expongo los recursos productivos del fracaso así como los peligros de la negación de esta experiencia.

Palabras clave: fracaso, desarraigo, épica, literatura caribeña 


\section{The Fruitfulness of Failure}

In one of its entries for the word fracaso (failure) the Dictionary of the Spanish Royal Academy (DRAE) offers a nautical image: "Dicho especialmente de una embarcación cuando ha tropezado con un escollo. Romperse, hacerse pedazos y desmenuzarse." To break and to shatter appear also to define the related word derrota (defeat), and the DRAE adds another nautical meaning to this word: a drift away from an original course. Hence, defeat suggests a path different from an initial itinerary. This essay discusses the importance of failure in order to conceive other routes that are unpredictable, broken, or dislocated from the one that has been previously set. This is done by reviewing some Insular Caribbean Hispanic novels of the twenty-first century. The Cuban, Dominican, and Puerto Rican writers that I address here, most of them little-known, are particularly interested in exploring wreckages as constituent processes of their own subjectivity. Most of these narratives indicate a rupture with the simplicity of tragic or heroic discourses, and propose new ways of dealing with the past and with memory. I am guided by the question: What is the productiveness of debris in the Caribbean?

To answer this question I explore the way in which some novels display both the limits and dangers of acknowledging defeat as well as its possibilities and resources. The experience of defeat is crossed by a tension between annihilation and fixedness on one hand, and openness and mobility on the other. If the first pair points toward total dissolution or conservative nostalgia once the original course is lost, the second pair can be associated to a positive conception of rootlessness in which the loss of a structured center facilitates utopian reformulations. When failure is related to the latter, it provides a multiplicity of alternatives, some of them bringing positive meaning to a loss. This positive meaning arises from the dynamic character of defeat, which might force us to drift away from the epic assumptions on which social, political or national identities have been established to seek more inclusive forms of community.

In Instrucciones para la derrota (2010), Ana María Amar Sánchez establishes a strong distinction between the defeated and the losers in order to categorize literary characters of contemporary Spanish and Latin American narratives. The experience of the defeated is linked to historical or material circumstances that do not affect their beliefs, while the experience of the losers produces a modification or change in those beliefs (Amar, 2010: 12-13). The distinction between defeated and losers has an ethical implication for Amar, because while the defeated stay faithful to their original principles, the losers eventually surrender to the hegemonic power. The problem with Amar's position is that it shows some ideological rigidity that is immune to learning from experience. The author values a simple acceptance of defeat without any kind of questioning introspection by the subject of the experience. Juan Duchesne, however, stresses the importance of the reflective work that emerges from a loss, and presents 
an opposite assessment when he says: "Una cosa es reconocer la derrota y otra asumir el fracaso. La segunda postura implica lucidez, reflexión ética y sobre todo una rara libertad que no existe frente a los dictámenes del éxito" (2010: 132). Embracing a critical ethic is a much more complex attitude than the simple recognition of an antagonist's success. Unfavorable experiences cast doubts about the assumptions on which the antagonism is built, and at the same time question the de-historization of divisive categories in the Caribbean (Puri, 2004: 4).

I propose then, to abandon differentiations between defeat and failure in order to discuss a common experience of loss. It is not my intention to cast these words into a moral dichotomy, because I wish to emphasize the unpredictability, historicity, and multiplicity of these experiences. When I talk indistinctively of defeat or failure I am alluding to a collective dimension that is often expressed by the particularity of a narrative voice or character. Failure is not necessarily a straitjacket; it can also be a dynamic existential or historical experience.

In Truth and Method, Hans-George Gadamer sustains the existence of productive prejudices that appear when we are confronted with certain experiences. For this philosopher, the true experience takes place when facts deny our preconceptions (1989: 316-317). This unplanned learning does not necessarily involve the abdication of certain principles, but it does imply a significant transformation of the way in which they were conceived. ${ }^{1}$ The latent danger in Amar Sanchez's proposal is that the immobility of a particular ethic will produce unproductive stagnation, because any possibility of change will entail a betrayal. That is why defeat is conceived by her perspective in heroic terms, and re-territorialized by an epic complex that erases its negativity. With regard to the defeated, Amar says: "Paradójicamente, su actitud antiheroica lo transforma en un héroe perfecto" (2010: 40). Faced with the risk of ethic relativism, Amar supports the heroic immobility of those who do not surrender their banners and take refuge in their certainties. There seems to be an attitude that denies defeat the possibility of a true experience.

On the contrary, a productive opening is embraced by Reinhart Koselleck when he says: "en el hecho de ser un vencido reside un potencial inagotable de conocimiento" (2001: 92). The knowledge inspired by defeat is the basis of historical changes because it is produced out of the need to reformulate a history that was different from what was initially intended. For Koselleck, this reformulation is derived from a dialectic relationship between two categories of knowledge: the "space of experience" and the "horizon of expectation" (2004: 306-327). The relationship between both produces a productive tension for political praxis. A proposal that understands failure as a space of experience can be projected into a

\footnotetext{
${ }^{1}$ In this sense, the "paradigm of desengaño" that John Beverley sees in certain left-wing intellectuals who reject the armed struggle should not necessarily lead us to conclude that there has been a shift away from utopian ideals (2011: 99), but that there has been a strategic change in perspective derived from revisiting the experience of defeat.
} 
horizon of expectations for emancipation. The effectiveness of failure comes from its constant dialogue with, and movement towards, the demands of a desired future. Defeat, then, entails the contingency of its own historicity. Its unresolved nature relies on a recurrent de-centering of interpretative assumptions.

In a similar way, Beatriz Sarlo advocates a critical rootlessness based on

un corte por extrañamiento que desvíe la percepción de su hábito y la desarraigue del suelo tradicional del sentido común. La puesta en cuestión de lo acostumbrado es la condición de un conocimiento de los objetos más próximos porque permanecen ocultos de la familiaridad que los vela. (2005: 55)

I propose, then, the notion of rootlessness not simply as national or geographic displacement, but as the loss of the certainties upon which our vision of the world is based, including our relationship with the past. Defamiliarization could be a way of perceiving Walter Benjamin's wreckages of history and refocusing on the catastrophe caused by the storm of progress. Wreckages are resources that, far from meaning immutability, inscribe themselves in the fugacity of historical time (2007: 65-76). Thus, I propose that we root-out our historicist teleologies.

The unpredictability of defeat is contrary to the fixedness of traditional epic. Both Homeric epic and classical tragedies share a vision of their heroes as higher beings compared to the rest of mortals. Heroic victories, as well as tragic falls, represent exemplary apotheoses for certain cultural groups. In Plato's Cratylus, Socrates claims that epic heroes are demigods, while in his Poetics, Aristotle emphasizes tragic heroes' moral greatness. This superiority justifies a cult to the heroes that aims to legitimize the identity or the cohesion of a community under the mythical origin that they represent. It is predicated on arete, a term of difficult translation which refers to values of nobility and excellence. The heroic is intrinsically connected to the idea of noble, semi-divine, or "pure" lineage. This mythical filiation was not exclusive of the Greeks; it is also present in many other cultures, as pointed out by Édouard Glissant. ${ }^{2}$ What these cultures have in common is that they organize their respective communities under the principles of genesis and lineage (Glissant, 2002: $60)$. While distinguishing heroes from the rest of human beings, the traditional epic "puts together the constituent elements of the community while excluding those alien to it" (2002: 37). For the Martinican poet, the epic refers to an emerging awareness that is also exclusionary (2002: 37). The model operates through an exclusion that discriminates the other, because it requires an origin that is fixed and immutable.

${ }^{2}$ Glissant provides examples from the Old Testament, the Chanson de Roland, the Nibelungen, the Kalevala, the Sacred Books of the Hindus, the Icelandic sagas, the PopolVuh and the Chilan Balam (2002: 37). 
I therefore understand the heroic as a compulsion for the origins. Most social groups and political systems in the Hispanic Caribbean have been built on this kind of discourse, no matter whether they are capitalist or socialist. This happens through an operation that denies the constant presence of the catastrophe and its debris. When defeat becomes impossible to evade, it is invested with heroic features that turn its exceptional nobility into a tragic epic. This has already happened, for example, with a good part of the Puerto Rican nationalist imaginaries. ${ }^{3}$

Any glance at the history of the Caribbean will present the reader with more defeats than victories, more ruptures than continuities, more traumas than plenitude. It seems that with epic discourses the region avoids a memory more painful than triumphalist, more dystopian than idyllic, more contingent than unequivocal. Caribbean memory is about indigenous extermination and African slavery, sugar plantations and Imperial economic and military interventions, is about the perennial crossbreeding of multiple migratory movements forced or painful, of racism, homophobia and poverty. Certainly this memory also includes the various resistances to these circumstances, but these can hardly fill an epic pattern of pure, privileged, or noble lineage linked to an unequivocal and static source. As Antonio Benítez Rojo said:

todo caribeño, al final de cualquier intento de llegar a los orígenes de su cultura, se verá en una playa desierta, solo y desnudo, emergiendo del agua salada como un náufrago tembloroso, sin otro documento de identidad que la memoria incierta y turbulenta inscrita en las cicatrices, en los tatuajes y en el color mismo de su piel. (1989: 241)

The Caribbean subject has much more to do with a naked castaway with a fragile and uncertain memory than with a traditional epic or tragic hero. His or her nakedness speaks of a constituent rootlessness and not of some legitimizing origin. In this sense, I share Yolanda Martínez San Miguel's perception of certain insufficiencies in the theories of the "coloniality of power" by scholars like Aníbal Quijano and Walter Mignolo (2014: 8). Andean cultural models -and others with a predominantly sedentary indigenous population - on which these theories are based, take for granted strong ancestral linkages with specific territories. However, this phenomenon does not seem to be the predominant element in the configuration of the uprooted caribeño identity, although there are exceptions in certain areas of the region. ${ }^{4}$ Forced nomadism has been much more frequent. This historical specificity produces what Rosi

\footnotetext{
${ }^{3}$ The poem Omeros by Derek Walcott can be thought of as an exception to this Caribbean practice because it poses a type of choral, bastard or illegitimate epic that neglects lineal lineage. It is interesting to mention that the title of the speech given at the Nobel Prize in 1992, "The Antilles: fragments of an epic memory", signaled that what is central to Walcott is not an original epic memory but its fragments.

${ }^{4}$ Consider, for example, the Colombian black populations originated in former palenques or, the Miskito communities in the Central American Caribbean coast.
} 
Braidotti calls a "nomadic subject" that entails subjectivities with porous borders that constantly decode various cultural territories (1994: 62-63).

What are the consequences of such displacements? Sigmund Freud's 1917 famous essay "Mourning and Melancholy", has prompted a long psychoanalytic debate around the two terms as different modes of relationship with a lost object. According to Freud if mourning makes it possible to remedy the loss by transferring the libido to a new object, melancholy instead projects that loss on the ego, in a movement of narcissistic identification with the lost object (Agamben, 2001: 152). Based on Freud's theory, melancholy has often been defined negatively. Postcolonial and Feminist studies, for example, reproduce the Freudian view. Paul Gilroy's Postcolonial Melancholia (2005) argues that British melancholy derives from the suppression of the historical memory of colonial practices. This suppression induces Britons to embrace white racism against ex-colonial subjects who threaten their historical amnesia. For Judith Butler, in turn, melancholy is a form of social regulation designed to reproduce standard behaviors with their respective exclusions. At the level of sexual politics, melancholy reflects the repression of homosexual desire in Western heterosexual standards, a repression that reinforces gender roles (1995: 165-180). Butler detects a contradiction according to which masculinity must reject its feminine inside, but paradoxically, feminine is imposed as the object of desire. In another example, Ann Ling Chen's The Melancholy of Race: Psychoanalysis, Assimilation, and Hidden Grief asserts that racial melancholy in the United States emerges from the feeling of loss of an idealized social unity. This loss is compensated by a paradigm of white supremacy that, also in a paradoxical way, requires the recognition of a racialized Other to sustain its own identity.

Against this negative view of melancholy, both José Lezama Lima and Giorgio Agamben have seen in melancholy a creative resource. Belonging to the intellectuals of the so-called "Republican frustration" generation, Lezama Lima developed, from the 1930s to the 1970s, a personal poetic in which, as a Catholic writer, he acknowledged the loss of an original unity. This loss accounts for the history of failure, exile, and marginalization lived by characters like Martí, the Aleijadinho, Bolívar and Miranda. It can only be remedied through the reflection of what was lost; that is, through what Lezama Lima conceived as the poetic image. The image sutures the vacuum of a reality, unified or original, that remains inaccessible to man. Melancholy transfigures absences into poetical images. For example, in his novel Paradiso, the protagonist observes the reflection of his dead father's image in a jack's game.

The concept of a productive loss is explored carefully by Agamben. For him, melancholy is a state in which the desire to recover what was lost promotes a phantasmatic capacity of the unobtainable (2001: 53). Consequently, Agamben concludes that "melancholy appropriates its object only when it asserts its loss" (2001: 54). It is clear that melancholy is 
fertile as it works on the loss to open a space to the unreal. In doing so it swings the doors open for imagination and creative production (2001: 54). If Agamben sees the loss as the condition of possibility for art, Benjamin perceives it as the condition of possibility for politics:

Para Benjamin, desde luego, la desolación melancólica ante la miseria pasada no sería, como en Freud, un bloqueo de la praxis, sino todo lo contrario: condición de posibilidad de toda praxis genuina. Sin tal impulso melancólico no habría praxis, sino pura técnica, pura adaptación conformista a la "borrasca que llamamos progreso". (Avelar, 2000: 172)

In the field of Latin-American studies, particularly in the South Cone, there has been much discussion about melancholy and its connection to memory in the context of the political defeat of the left, the horror of military dictatorships, and the subsequent implementation of neoliberal models. Idelber Avelar speaks of an unresolved mourning, an experience in which the loss cannot be replaced by a metaphor (2000: 283, 288). Instead of being referred by the unity of the symbol, trauma can only be referred by allegory; that is, by the trope of the remaining fragments left after defeat. This defeat expressed itself in the impossibility of an all-encompassing writing such as the one produced during the Latin American Boom.

Christian Gundermann in turn, proposes to substitute the "work of mourning" by "melancholic work" (2007: 16). His proposal loses sight of the ambiguities and even of the continuities between the moments of both "works". Gunmermann's mourning and melancholy have a Freudian logic, but their Freudian worth is reversed. For him melancholy is a consistent way to resist the status quo, in opposition to mourning which implies a closing of the political. This is why he criticizes Hugo Vezzeti's view on how to deal with the memory of loss, which is more ambiguous about the value of mourning. Vezzeti's concern is that "the rejection of mourning" may lead to a petrified denial of tragedy. Petrification of memory happens either by denying the past or by embracing the same epic of the past (2002: 16). In line with the perspectives of Gadamer and Koselleck, Vezzeti offers a dynamic view on experience. Defeat is continuously re-written in its historical transience because there is no "intransient essential truth" (2002: 192).

Sharing Vezzeti's concerns, Nelly Richard warns us that one of the consequences of the memory of loss is an "intensificación nostálgica del recuerdo y de su épica del metasignificado" (2007: 140). This nostalgic epic entails a "mitologización del pasado histórico como emblema de pureza e incontaminación [...] para remediar la falta de ejemplaridad histórica del presente" (2007: 140). The experience of failure carries the risk of an epic reterritorialization, which constitutes a compensatory memory.

This brings into the fore what I call "quehaceres of memory"; an expression which refers both to the necessary work that must be done and to the question of what to do with what we remember. It is necessary that 
we uproot memory. Both Vezzetti and Richard warn us about the dangers of the immutability of remembrance. To avoid this risk, Vezetti's advocates a certain kind of forgetfulness by which the certainties of memory are suspended and the past can be redefined (2002: 37). Richard, on the other hand, relativizes the rejection of melancholia by postcolonial studies in order to recover a productive negativity of memory: "Habrá [...] que cuidarse de no borrar la negatividad de una falla histórica cuya perforación debe seguir incomodando las retóricas sustitutivas y falsamente reparatorias del recuerdo-en-orden" (2001: 107). In fact, Vezzeti sees in mourning what Richard sees in melancholy - losses that refuse any autocelebratory capture. Vezzeti's mourning memory or Richard's melancholic memory serve as forms of resistance, which not only call into question the "monologic totalizations" of official history (Richard, 2007: 124), but also the histories of the defeated and the marginalized. As Richard asserts, this resistance will dismantle "el cierre explicativo de las totalidades demasiado seguras de sí mismas" (2007: 138). In this way, we avoid what Svetlana Boym describes as "restorative nostalgia", a reconstruction of the past in terms of absolute truth (2001: xviii).

A security based on an unmovable and "authentic" memory brings us back to the compulsion for the origins and to the embrace of epic discourses. Glissant warns us that "épica es [...] el grito que, tradicionalmente, necesita emitir la comunidad para contrarrestar la amenaza de inseguridad que pesa sobre su identidad" (2002: 38). This defensive position leads to a constant in some recent novels: a normative identity that denies body and pleasure. Epic requires what Josefina Ludmer calls "cronopolítica" [chronopolitics] designed to subject individuals to a teleological reason under which the ludic and the libido are illegitimate or postponed for a utopian future that never arrives (2010: 27). Instead, chronopolitics requires the solemnity of martyrology; a paradox if we recall that Herbert Marcuse thought of utopia as the liberation of alienated labor and the achievement of a collective Eros (Levitas, 1990: 140). I propose to abandon the teleological imperative and to reconfigure memory and everyday practices in such ways that pleasure does not have to be the subject to the purpose of triumph. Pleasure should emerge from a constant negotiation between the individual and collective emancipation. In the uncertainty generated by defeat, we may conceive a spatial, epistemic, or identity rootlessness that is pleasant.

Epic, rootlessness and memory are fragments of the various Caribbean shipwrecks represented in several narratives from Cuba, the Dominican Republic, and Puerto Rico published since 2000. The beginning of the 21st century seems to bring a change of sensibility — which is not chronologically precise since we can find important precedents in the twentieth century ${ }^{5}$ - with respect to heroism in official discourses and

\footnotetext{
${ }^{5}$ To examine some literary works related to the theme of failure written by authors like Borges, Arlt, Onetti and Aira, see the volume edited by Yvette Sánchez and Roland Spiller (2009).
} 
their contra-hegemonic proposals. This heroism not only proved inadequate to represent Caribbean reality but also was counterproductive, as it drowned the utopian elements that initially fed some aesthetic and political projects.

\section{Against the Epic}

Epic imaginaries are often amnesic or compensatory operations of the experience of failure. In Muerte de nadie (2004) written by the Cuban Arturo Arango and in Simone (2013) by the Puerto Rican Eduardo Lalo, the heroic is expressed through the glorification of official revolutionary discourse or of intellectual figures. In both novels, the authority of the heroic requires a single, "authentic" truth. By contrast, the Cuban novel La novela de mi vida (2002) by Leonardo Padura and the Dominican testimony Caamaño. La última esperanza armada (2000) by Manuel Matos Moquete dramatize the conflict between such heroic truth and the subaltern voices struggling to shatter grandiose discourses. These non-heroic subjectivities acquire agency by opening themselves to a creative and emotional dimension.

Simone exalts a lettered epic in which the intellectual is conceived as a figure of resistance against neoliberal and consumer society. Defending the absolute values of writing and art, the intellectual stands as a "heroic defeated", marginalized from society because he rejects any negotiation with the dominant order. Due to the hierarchical worldview of its protagonist and his isolation from the crowd, this novel continues a modernist tradition (Rodó, Darío) and specifically a Puerto Rican one (Pedreira and Marqués) in which anti-imperialism does not necessarily imply an anti-classist or democratic position. I detect a defensive posture in the narrator that tends to articulate a conservative counter-hegemonic discourse, as he, as an intellectual, needs to differentiate himself from what he considers the dominant mediocrity. His discourse restores the selfcomplacent vision of the intellectual as a privileged figure with an immutable and "authentic" cultural authority.

Building on a very different experience, the works of Padura and Arango propose alternative resolutions to the failure of the socialist utopia. Padura's novel suggests a reinvention of the Cuban nation from an awareness of failure. This imaginative rewriting is possible thanks to the loss of the homeland suffered by the two main characters. The recreation of the nation's origins is done without appealing to the heroic. Therefore Padura does not focus on José Martí, but on romantic poet José María Heredia, who is no exemplary martyr but a disillusioned poet who gave in to the colonial power for personal reasons. Heredia is presented as an alternative to the national hero for all Cubans, including the protagonist Fernando Terry, who failed to adjust to patterns of good revolutionary behavior. Lost illusions function as triggers for the re-composition of 
affective ties broken by the ideological imperatives, while they also wake up an erotic desire that seemed subsumed by resentment and despair.

If Padura's novel focuses on the experience of failure to recover its productive role, Arango's, on the other hand, focuses on the revolutionary epic to show its sterile denial of such failure. Immersed in a regime that rejects the space of experience necessary for political action (Koselleck), Arango's characters are suspended in the amputated history of a dystopic island. The novel shows the drama of a revolution that has been absorbed by the restorative reflux of an official history that hides its own ruins, not as a result of liberal progress but because of socialist utopia. Muerte de nadie exposes how utopia is dumped into a dystopia characterized by the erasure of desire and memory. The official writing denies failure and imposes a restrictive conception of history.

The need of an open memory is addressed in the testimony of a failed landing by Dominican guerrillas during the 1970s. Caamaño. La última esperanza armada describes the tension between what I denominate the "first-person protagonist of the plot" and the "first-person critic-in-process". We witness the configuration of a subjectivity that lacked autonomy during the recalled political action in the past but achieves autonomy through interpretative action at the present. This first-person critic-in-process that emerges from the narration of defeat is different from the epic protagonist of the testimonial genre (Beverley, Duchesne). At the same time, he vindicates the utopian impulse. In this way, the critic-inprocess seeks to fill in the gaps of Dominican official history, without accepting the taboos of the left and without falling to the defeatism of post-Trujillista or Balaguerista hegemony.

\section{In Defense of Rootlessness}

When we abandon traditional negative visions of rootlessness we can glimpse into its potentiality. My goal is not to romanticize this phenomenon, common in the Caribbean's history, but to try to reverse its effects. Rootlessness can be a mobilizing resource that frees the Caribbean people from the single-root structures that Guilles Deleuze, Felix Guattari, and Glissant condemned. The contingent dynamism provoked by continuous physical and psychic displacements boosts regenerative practices of marginalized subjects. Such are the cases of Cuban characters in Mylene Fernández Pintado's Otras plegarias atendidas (2002) and Margarita Mateo Palmer's Desde los blancos manicomios (2008) - these characters hardly follow patterns of official revolutionary discourse- and of the Dominican-york protagonist in Junot Diaz's novel The Brief Wondrous Life of Oscar Wao (2007).

Fernández Pintado's Otras plegarias atendidas advocates the renouncement of origin and belonging. Its main character develops a sensibility that dismisses the idea of a totalitarian root. The failure of socialist teleology allows the emergence of what I call a "condition of 
transitory-ness" in the protagonist. With the disappearance of expectations about the future, unpredictability arises and time can be released. The condition of transitory-ness entails an enjoyment that is neither measurable nor lucrative, and dispenses from any obligation with the future. It encourages new forms of community that are grounded on the dynamism of the upcoming.

Mateo Palmer narrates the process of enlightenment of a fragmented conscience after a utopian catastrophe. Lacerated bodies, deranged subjectivities, broken stories, characters in permanent anxiety, are the elements that make up the map of insular rootlessness. Centered in the protagonist's psychiatric crisis, the story shows how she abandons and transgresses the boundaries that confine and immobilize her subjectivity. Such displacement implies coming to terms with her trauma and transforming it into a propitious engine to favor the rebuilding of a new existential and historical territoriality.

Displacements also mark Diaz's novel. If we accept the distinction proposed by Glissant between territory and place, The Brief Wondrous Life of Oscar Wao seems to fictionalize the idea of place. Narrative places become areas where the text decodes the references that demarcate the territory, and where the uprooting of identity occurs. However, identity categories are not completely annulled. Places respond to an anthropophagic practice in which different territories (geographical, racial, economic, linguistic, sexual, temporal and aesthetic) persist, but recycled under a permanently unresolved tension. Such a phenomenon articulates a new form of center-less cultural anthropophagy through the figure of the loser. Oscar is a loser that has been expelled from the logic of capitalist profit. His symbolic-political recycling does not intend to erect new territories or binary rearrangements, but to uproot old territories into new places.

\section{Quehaceres of Memory}

What is to be done when memory is subject to epic duties and to the beatings of rootlessness at the same time? This problem has different resolutions in the novels Letramuerto. Asesinato en La Tertulia (2010) by Wilfredo Mattos Cintrón, Charamicos (2003) by Ángela Hernández, and Barataria (2012) by Juan López Bauzá. Memory can petrify around absolute certainties, as it happens to Chiquitín, who is obsessed with the political status of Puerto Rico in Barataria. Or memory can be constantly reconstituted according to an ethic-in-situation and to utopian desire. That is the case of the Puerto Rican characters in Letramuerto and the Dominicans in Charamicos.

Declassification of intelligence files about pro-independence Puerto Rican cadres serves Mattos Cintrón as an opportunity to denounce past state repression and to develop a critical memory of the Puerto Rican left in his detective novel Letramuerto. This critical memory partly blames the defeat of the Socialist independence movement on the reproduction of 
stigmatizing and discriminating practices of the colonial state the movement was supposed to fight. Shaped by a conception of history as an unending process, the novel supports the idea of a collective responsibility for the militants' failure. The defeated group was constituted by members of the Puerto Rican lettered city that saw themselves as builders of the nation. University activism, files, and newspapers ended up being forms of social control that helped drown the nationalistic utopia. Within the context of the current neo-liberal economy in the island, this revision of the militant memory rethinks the independence movement in a more horizontal and democratic way vis-à-vis the lettered activism of the past.

Charamicos also explores a memory of the left. It describes different subjective positions of the Dominican activists in their struggle against Joaquín Balaguer's authoritarian regime during the 1970s. The novel shows that some failures of utopia were linked to a civilizatory reason. With the advantage of hindsight, Hernández reconstructs a memory widened by two different forms of subjectivity that I call "volitional epic" and "hesitant criticism". On the one hand, the volitional epic brings a popular female subject into a martyrological History, and on the other hand, hesitant criticism empowers a popular critical subject against the dominant patriarchal and teleological discourse. Hesitant criticism is particularly productive to problematize the modern prejudices of militants inclined to expropriate the historicity of popular subjects for the sake of modern revolutionary utopia. Hernández respects the subjectivity of a volitional epic, but she is closest to the hesitant criticism of her characters, as this emerges as a model less restrictive and more humane.

In Barataria we find two different ways of dealing with memory through the rewriting of Cervantes's Don Quixote in a Puerto Rican style. There is Chiquitín (Don Quixote), who remains immobilized by his compulsion to search for origins; he needs to resort to a (tragic) national epic to reassert a strong identity. And there is Margaro (Sancho Panza), whose memory is strategic rather than normative. Margaro offers the possibility of looking beyond the boundaries imposed by the legal status of the island, and of accepting the constituent failures of a pan-Caribbean culture. He differs from Chiquitín because he is aware of power asymmetries. I associate this attitude with an "erratic" territoriality that is characteristic of a popular ethic-in-situation and of an evasion from the nation's mandates.

Thinking from the position of defeat demands that we relocate ourselves in a place hardly valued by society. On the contrary, identity, origins, heroism, and teleology are common places that too often characterize the Hispanic Caribbean. The epic allows us to run away from our constituent shipwrecks. It is not too difficult to read in such omission nationalistic emulations of prestigious cultural models, with their magnificent foundational myths. But Caribbean epics must be understood not only as pure imitation, but also as a genuine product of non-Western 
cultures that were embedded in the region even before the creation of the nation states. The emergence of the epic has to do with the need to establish cohesive links within communities. However, any community based on epic-ness is condemned, not only to repeat its own failure, but to the erasure (symbolic or literal) of other communities. To overcome this problem we must listen to what failure has to tell us.

A community of heroes is not desirable because it will always demand a place above the rest. In order to survive, it requires inequality in its constitution. As an exemplary figure, the hero imposes a unique vision above ideology, class, gender, or ethnicity. The hero dilutes us in a homogeneous and monological crucible of the One. On the contrary, failure returns us to our uniqueness through a departure from the norm, from the standard.

The Caribbean, as a place of multiple encounters and geographic, imperial, national, ethnic and linguistic intersections, is a particularly fertile space to think about contingent, unplanned territorialities departing from the norm. The Caribbean is a community of singularities more than one of universals. But, without this conscience, it is virtually impossible to weave a network of strategic relationships that relate individual emancipation with the collective. Failure becomes an annihilating experience only when we attempt to neutralize it through the reconstitution of an indivisible and monolithic origin. "Restorative nostalgia" is the opposite of an empowering defeat. Of course, such empowerment does not warrant new certainties. Defeat closes the possibility of going back to the past; here lies its dynamic potentiality: failure impels us to continue sailing, no matter how battered the boat is.

\section{BIBLIOGRAPHY}

AgAmBen, Giorgio (2001), Estancias. La palabra y el fantasma en la cultura occidental. Valencia, Pretextos.

AmAR SÁnCheZ, Ana María (2010), Instrucciones para la derrota. Narrativas éticas y políticas de perdedores. Barcelona, Anthropos. DOI: <http://dx.doi.org/10.5195/reviberoamer.2013.7065>

Arango, Arturo (2004), Muerte de nadie. Barcelona, Tusquets.

AVELAR, Idelber (2000), Alegorías de la derrota. La ficción postdictatorial y el trabajo de duelo. Santiago de Chile, Cuarto Propio.

BeNítez Rojo, Antonio (1989), La isla que se repite. Barcelona, Casipoea. DOI: http://dx.doi.org/10.2307/29740282

BENJAMIN, Walter (2007), Conceptos de filosofía e historia. La Plata, Terramar.

BEVERLEY, John (2011), Latinoamericanism after 9-11. Durham; London, Duke University Press. DOI: <http://dx.doi.org/10.5195/reviberoamer.2014.7098> Boym, Svetlana (2001), The Future of Nostalgia. New York, Basic Books. 
BRAIDOTtI, Rosi (1994), Nomadic Subjects: Embodiment and Sexual Difference in Contemporary Feminist Theory. New York, Columbia University Press. DOI: <http://dx.doi.org/10.1177/1350506815590583>

BUTLER, Judith (1995), "Melancholy Gender/Refused Identification", in Psychoanalytic Dialogues, 5, 2, pp. 165-180. DOI: <http://dx.doi.org/10.1080/10481889509539059>

CHENG, Ann Ling (2001), The Melancholy of Race: Psychoanalysis, Assimilation, and Hidden Grief. New York, Oxford University Press.

Deleuze, Gilles and GuatTARI, Felix (2005), A Thousand Plateaus: Capitalism and Schizophrenia. Minneapolis, University of Minnesota Press. DOI: <http://dx.doi.org/10.2307/203963>

DíAz, Junot (2007), The Brief Wondrous Life of Oscar Wao. New York, Riverhead Books.

Diccionario de la Real Academia Española (DRAE). "Fracasar"; "Derrotar". <http://www.rae.es/recursos/diccionarios/drae> (October 18, 2014.)

DUCHESNE WINTER, Juan (2010), La guerrilla narrada: acción, acontecimiento, sujeto. Río Piedras, Ediciones Callejón.

Fernández PINTAdo, Mylene (2002), Otras plegarias atendidas. La Habana, Ediciones Unión.

GADAMER, Hans-Georg (1989), Truth and Method. London, Continuum. DOI: <http://dx.doi.org/10.1007/978-94-010-2762-5>

GILroY, Paul (2005), Postcolonial Melancholia. New York, Columbia University Press. DOI: <http://dx.doi.org/10.1177/0090591708321036>

GLISSANT, Édouard (2002), Introducción a una poética de lo diverso. Barcelona, Editorial del Bronce.

Gundermann, Christian (2007), Actos melancólicos. Formas de resistencia en la posdictadura argentina. Rosario, Beatriz Viterbo Editora.

Hernández, Ángela (2003), Charamicos. Santo Domingo, Editora Cole.

KoselleCK, Reinhart (2006), "Espaço de experiência e horizonte de expectativa: duas categorias históricas". Futuro Passado. Contribuição à semântica dos tempos históricos. Rio de Janeiro, Contraponto-Ed. PUCRio, pp. 306-327.

(2001), Los estratos del tiempo. Estudios sobre la historia. Barcelona, Paidós.

LALO, Eduardo (2013), Simone. Buenos Aires, Ediciones Corregidor.

LEVITAS, Ruth (1990), The Concept of Utopia. London, Philip Alan. DOI: <http://dx.doi.org/10.1057/9781137314253.0001>

LeZAMA LIMA, José (1993), La expresión americana. D.F., Fondo de Cultura Económica.

(1981), El reino de la imagen. Caracas, Biblioteca Ayacucho.

LóPEZ BAUZÁ, Juan (2012), Barataria 1-2. San Juan, Libro AC.

LUDMER, Josefina (2010), Aquí América Latina. Una especulación. Buenos Aires, Eterna Cadencia.

Martínez San Miguel, Yolanda (2014), Coloniality of Diasporas. Rethinking Intra-Colonial Migrations in a Pan-Caribbean Context. Nueva York, Palgrave Macmillan. DOI: <http://dx.doi.org/10.1353/crb.2014.0025> 
Mateo Palmer, Margarita (2008), Desde los blancos manicomios. La Habana, Letras Cubanas.

Matos Moquete, Manuel (2005), Caamaño. La última esperanza armada. Santo Domingo, Publicaciones Matos Moquete.

Mattos Cintrón, Wilfredo (2010), Letramuerto: asesinato en La Tertulia. San Juan, Ediciones La Sierra.

PADURA, Leonardo (2002), La novela de mi vida. Barcelona, Tusquets. DOI: <http://dx.doi.org/10.2307/20062905>

Platón. "La República". Nueva Acrópolis. <http://www.nuevaacropolis.es/filiales/libros/Platon-La_Republica.pdf> (December 13, 2014).

PURI, Shalini (2004), The Caribbean Postcolonial: Social Equality, Postnationalism, and Cultural Hybridity. New York, Palgrave MacMillan.

RichaRD, Nelly (2007), Fracturas de la memoria. Arte y pensamiento. Buenos Aires, Siglo XXI.

SÁnCHEZ, Yvette and SPILleR, Roland (eds.) (2009), Poéticas del fracaso. Tubinga, Gunter Narr Verlag.

SARLO, Beatriz (2005), Tiempo pasado: cultura de la memoria y giro subjetivo. Buenos Aires, Siglo XXI.

VezzetI, Hugo (2002), Pasado y presente. Buenos Aires, Siglo XXI.

WALCOTT, Derek (1992), "Nobel Lecture: The Antilles: Fragments of Epic Memory", Nobelprize.org. <http://www.nobelprize.org/nobel_prizes/literature/laureates/1992/w alcott-lecture.html> (September 23, 2012). DOI: <http://dx.doi.org/10.2307/40149064> (1990), Omeros. New York, Farrar. 